Document downloaded from:

http://hdl.handle.net/10251/37519

This paper must be cited as:

Pachés Giner, MAV.; Romero Gil, I.; Martínez Guijarro, MR.; Martí Insa, CM.; Ferrer Polo, J. (2014). Changes in phytoplankton composition in a Mediterranean coastal lagoon in the Cullera Estany (Comunitat Valenciana, Spain). Water and Environment Journal. 28(1):135144. doi:10.1111/wej.12020.

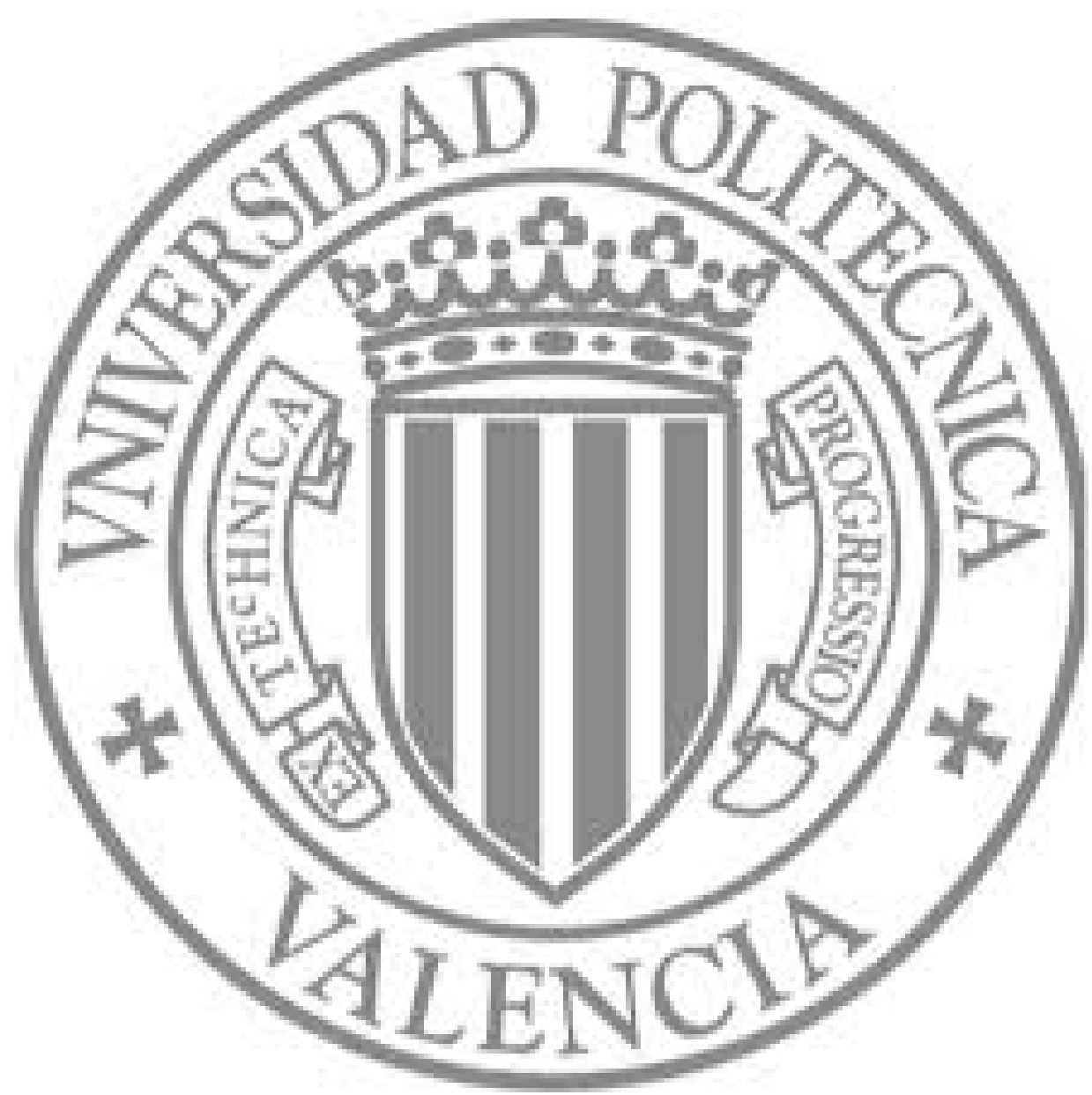

The final publication is available at

http://dx.doi.org/10.1111/wej.12020

Copyright Wiley 


\title{
Changes in phytoplankton composition in a Mediterranean coastal lagoon in the Cullera Estany (Comunitat Valenciana, Spain)
}

Pachés M, Romero I, Martínez-Guijarro- R, Martí CM, Ferrer J

Instituto de Ingeniería del Agua y Medio Ambiente

Universitat Politècnica de València, Camino de Vera s/n, 46022, Valencia, Spain

"Corresponding author. Tel.: +34963877616; fax: +34963879793; e-mail

mapacgi@upvnet.upv.es

\begin{abstract}
The Cullera Estany is a coastal lagoon located in a highly intensified agriculture and tourist area in Valencia. This coastal lagoon has connections with the sea that produce marine intrusion and generate a freshwater interface.

Four sampling campaigns were carried out during 2010 in order to analyze the phytoplankton composition and its relation to nutrient content through a Redundancy Analysis. Temperature, dissolved oxygen, nitrite and salinity are the main factors controlling the dynamics of phytoplankton community.

During July and October there is water column stratification, meanwhile in March there is a well mixed water column. In addition, in May and July campaigns hypoxia/anoxia conditions are detected at the bottom.

The most abundant phytoplankton groups are Diatoms and Cryptophyceae. Diatoms and Cyanophyceae respond positively to temperature whilst Cryptophyceae, Prasinophyceae and Dinophyceae respond to high salinity and dissolved oxygen values. Furthermore, picoplankton is correlated inversely with nutrient concentrations.
\end{abstract}




\section{Key words}

Phytoplankton community, Coastal lagoon, Mediterranean Sea, Redundancy Analysis

\section{Introduction}

Coastal lagoons have been defined as inland water bodies, usually oriented parallel to the coast, separated from the sea by a barrier and connected to the sea by one or more restricted inlets. The increase of eutrophy in these ecosystems has become more general during the last decades. The increase of anthropogenic use of littoral areas for residential, tourist activities and industry is one of the most important causes of eutrophication.

In the Mediterranean Sea, the eutrophication has been mainly related to high population and human use of the littoral (Puigserver et al. 2002). Furthermore, in the Valencia Region (Spain) there is another human activity causing water eutrophication which is intensive agriculture (Ramos et al. 2002). Although in aquatic ecosystems primary production is regulated through both biotic mechanisms and abiotic mechanisms (Reynolds 2006), nutrients are considered the main limiting factor for phytoplankton growth in shallow temperate ecosystems, where photon flux through the water columns does not impose restrictions to photosynthetic requirements (Pérez-Ruzafa et al. 2002). For this reason, the nutrient inputs derived from the agriculture induce an enhancement of primary production that can lead to severe eutrophication problems (Cloern 2001).

The main environmental factors recognized as controlling community structure of phytoplankton are physical (mixing of water, light, temperature and turbulence) and chemical (salinity and nutrients) (Brogueira et al. 2007). 
The problem of water eutrophication in Europe has resulted in a legal mechanism for improving the ecological quality of the water by the European Water Framework Directive (WFD 2000/60/CE). The regional government has to implement this Directive in all its waters, however to date no detailed study has been made of the quantity and quality of the water in many places under the WFD requirements. For that reason the aim of this research is to analyze phytoplankton community behaviour (composition) and its relation to nutrient content in a coastal stratified lagoon in the Mediterranean region. This study attempts to be a helpful preliminary research of the system in order to facilitate the further WFD implementation in this water body.

\section{Material and methods}

\section{Study area}

Cullera Estany is a microtidal coastal lagoon approximately 2400 metres long, 35175 metres wide and maximum depth of 7 metres, located near Cullera city (Valencia, Spain).

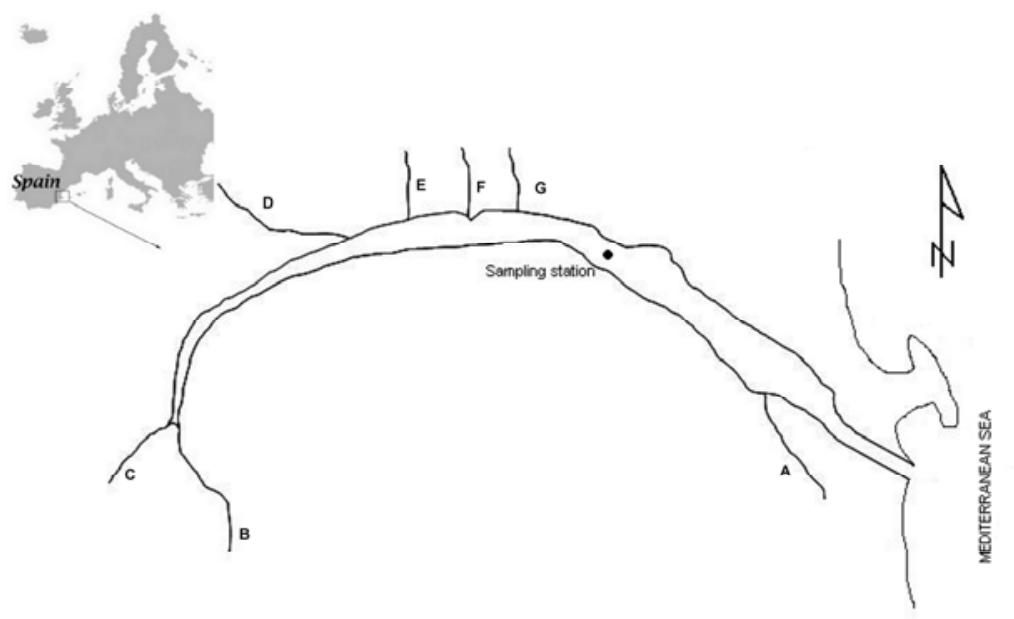

Fig. 1: Cullera Estany on the north-western Mediterranean coast. Location of sampling station. A-G irrigation channels 
This coastal lagoon was formed by the closure of a former fluvial estuary by a sand bar. In 1982, the sandy barrier was removed to enable Estany waters flow openly to the sea. Since then, this system usually behaves as a typical stratified estuary showing a marine water intrusion that generates a freshwater-saltwater interface (Vicente \& Miracle 1988). Freshwater inputs to the Estany come in depth from groundwater and in surface by inputs from several irrigation channels (Fig.1).

\section{Data acquisition}

Four field campaigns were carried out in March, May, July and October 2010 at one sampling station defined in the middle of the coastal lagoon (Fig.1).

At the sampling station, a multiparametric probe YSI was used to locate the freshwater-saltwater interface depth since it fluctuates. Once the interface was located, water samples were taken using a Density Interface Water Sampler (Mösso et al. 2008). This device allows taking samples at the interface and 10, 20, and 30 $\mathrm{cm}$ below. Two additional samples were also collected, one at the surface and other at the deepest depth.

Table 1 shows sampling campaign dates and depth profiles for the sampling station. In situ temperature, Dissolved Oxygen (D.O.) and turbidity were measured with the multiparametric probe YSI.

Samples for nutrient, salinity and chlorophyll a analysis were collected in $2 \mathrm{~L}$ plastic bottles. Samples for phytoplankton analysis were collected in $250 \mathrm{~mL}$ bottles and treated in situ with glutaraldehyde ( $2 \%$ final concentration) as indicated by Sournia (1978). Both bottles were kept at $4^{\circ} \mathrm{C}$ until their arrival at the laboratory.

Once in the laboratory, samples were divided into several proportional parts, following the conservation procedures suggested by APHA (1998). Samples were 
filtered through cellulose acetate membrane filters of $0.45 \mu \mathrm{m}$ (Millipore HAWP) for nutrients (except for total phosphorus (TP) which was measured on unfiltered samples) and salinity. Membrane filters were used to determine chlorophyll a content.

For the nutrients analysis (ammonium, nitrite, nitrate, soluble reactive phosphorus (SRP), TP and orthosilicic acid) an Alliance Instruments auto-analyzer was used, following the methodology described by Treguer \& Le Corre (1975), and taking into account Kirkwood et al. (1991) and Parsons et al. (1984) considerations. On the determination of chlorophyll a the trichromatic method based on spectrophotometry (APHA 1998) was used.

Salinity was measured with a Portasal Guildline 8410 A, calibrated with the suitable standards (I.A.P.S.O. Standard Seawater, Ocean Scientific International Ltd, K15= $0.99986, S=34.995 \%$ )

Algal counts were made by an epifluorescence microscopy (Vargo 1978) with a Leica DM2500 microscope, using a 100× oil-immersion objective (Pachés et al. 2012). Using epifluorescence microscopy, phytoplankton cell shapes, flagella, or other cell extensions can be observed, together with the size and shape of the chloroplasts and their red or orange autofluorescence, which provide the basis for identification (Havskum et al. 2004). Standard keys and manuals were used for taxonomic determinations (Caljon 1983; Ettl 1983; Round et al. 1990; Tomas 1997)

\section{Statistical analyses}

The correlations between the phytoplankton composition and the environmental factors were assessed using redundancy analysis (RDA) which is a linear method of direct ordination using the CANOCO package (ter Braak 1986). All biological data used in the analysis were logarithmically transformed to stabilize variance and 
reduce the influence of dominant taxa on the ordination. RDA was performed using CANOCO for Windows 4.5 (ter Braak \& Smilauer 1998) with manual selection to identify the significance of the environment variables that best explain phytoplankton composition.

\section{Results}

\section{Physical and chemical water parameters}

Fig. 2 shows salinity, temperature, turbidity, D.O., nitrite, nitrate, ammonium, orthosilic acid, chlorophyll a, TP and SRP vertical profiles at the sampling station of Cullera Estany.

Water temperature oscillates between $12.4^{\circ} \mathrm{C}$ at 6.20 metres depth in March and $29.1^{\circ} \mathrm{C}$ at surface in July. In March, May and July the superficial water layer is warmer than the deeper, however in October the superficial water layer is colder (Fig. 2). Vertical temperature differences from the surface to the bottom reached 9.3 ${ }^{\circ} \mathrm{C}$ in July and $5.9^{\circ} \mathrm{C}$ in October. Moreover, it can be observed a sharp change in temperature in the first centimetres of the water column in October campaign. The maximum salinity value found in October at 6.40 metres depth $\left(35.63 \mathrm{~g} . \mathrm{kg}^{-1}\right)$ and the minimum value is found in July at the surface and at 0.30 metres depth $(<5$ g. $\left.\mathrm{kg}^{-1}\right)$. July and October present the largest rates of variation in salinity $\left(30.5 \mathrm{~g} \cdot \mathrm{kg}^{-1}\right.$ and 27.7 g. $\mathrm{kg}^{-1}$ respectively) that indicate a sharp halocline in the water column. D.O. concentration varies from under $1 \mathrm{mg} \cdot \mathrm{L}^{-1}$ in May at 6.70 metres up to $12 \mathrm{mg} \cdot \mathrm{L}^{-1}$ in July at 0.90 metres. In May and July campaigns anoxic/hypoxic conditions can be observed in the deepest part of the lagoon where less than $1 \mathrm{mg} \cdot \mathrm{L}^{-1}$ of D.O. is reached. 
The minimum turbidity value, 3.4 NTU, is found at 2.70 metres in October and reaches 12.2 NTU at 0.70 metres in March. All sampling campaigns reach highest turbidity values in the water layer located between 0.5 to 1 metres depth, except in October when turbidity values do not change too much throughout the water column. Nitrite concentrations range from $0.12 \mu \mathrm{M}$ at 0.90 metres in July to $8.09 \mu \mathrm{M}$ at surface in May. The highest nitrite values are always found in the superficial water layer. These values decrease and reach minimum values around 0.8 metres depth, especially in July campaign where at 0.90 metres nitrite value is $0.12 \mu \mathrm{M}$.

Nitrate is the most abundant nitrogen compound and its pattern is quite similar to the former. The minimum value found is $9.6 \mu \mathrm{M}$ at 6.10 metres depth in July and the maximum is $896.7 \mu \mathrm{M}$ at the surface in March. March and October campaigns have the highest nitrate values at surface. In addition, there is a decrease in nitrate values in the first meter of the water column in all campaigns.

The ammonium concentration ranges from $0.30 \mu \mathrm{M}$ at 0.60 metres in March to 201 $\mu \mathrm{M}$ at 6.10 metres in July. The pattern is similar for March and October campaigns increasing this value through the column up to $30 \mu \mathrm{M}$ in the deepest part. However, ammonium suffers a great increase in the deepest layer in July and May. Total phosphorus concentrations vary between $0.79 \mu \mathrm{M}$ at 1.10 metres in March to $28.25 \mu \mathrm{M}$ at 6.10 metres in July. There are two clear patterns among the campaigns for both TP and SRP. The first in March and October where concentrations do not vary too much between the surface and the bottom of the water column, and the second in May and July where the values increase from the superficial to the deepest layer reaching values up to $28.25 \mu \mathrm{M}$ for TP and $14.7 \mu \mathrm{M}$ for SRP. The orthosilicic acid varies between $16.8 \mu \mathrm{M}$ at 1.1 metres in March to $122.8 \mu \mathrm{M}$ at the surface in October. In March and October the highest values are found in the 
superficial water layer, and the content diminishes along the water column reaching the lowest values in the bottom. However in May and July campaigns, orthosilicic acid diminishes sharply until 1 metre depth, although it reaches the highest value in the deepest part of the lagoon. 

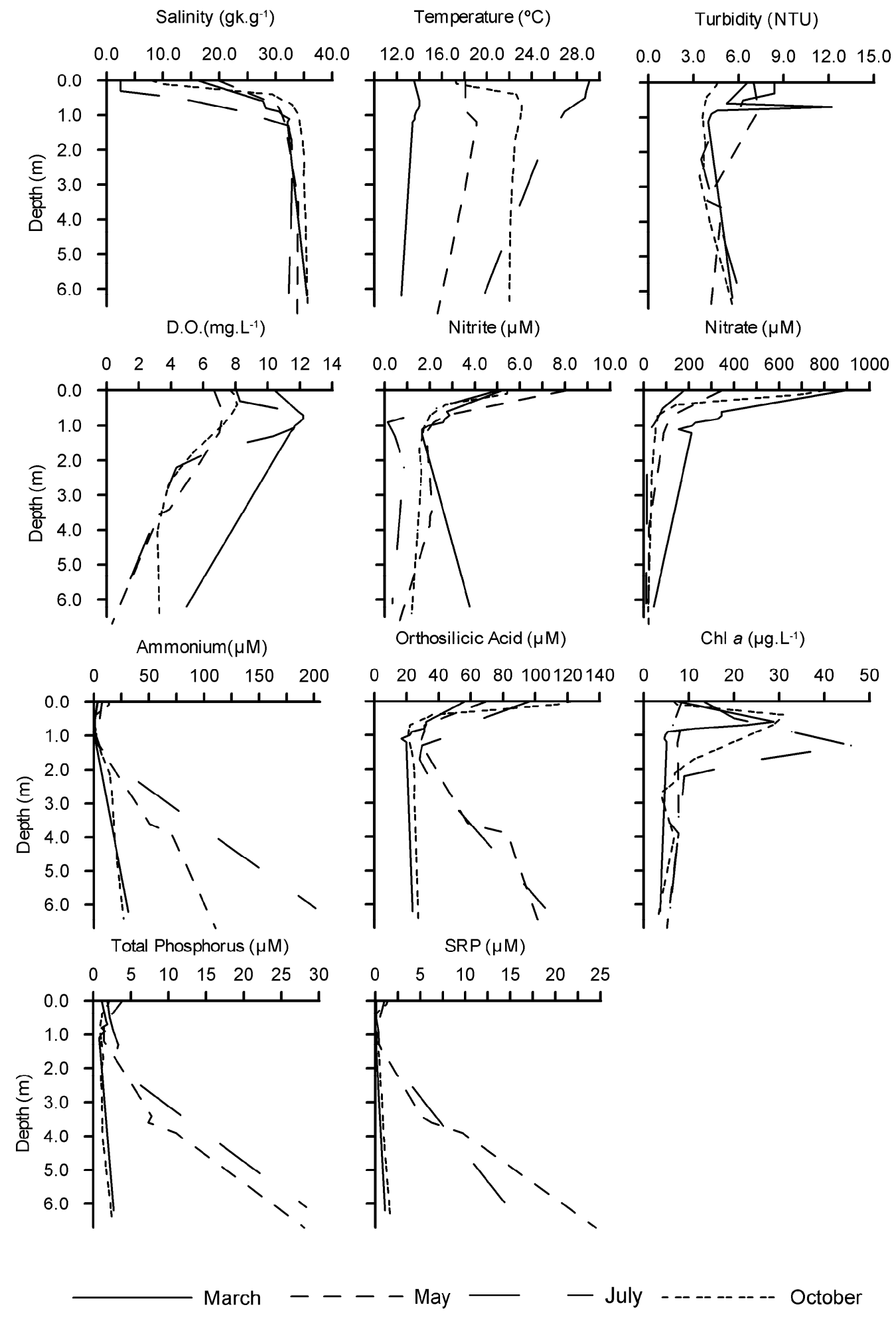

Fig. 2: Vertical profiles of physical and chemical parameters for the sampling station Phytoplankton biomass, composition and abundance

In Fig. 2, it can be observed that phytoplankton biomass, measured as chlorophyll a, varies between $3.05 \mu \mathrm{g} \cdot \mathrm{L}^{-1}$ in October at 6.40 metres depth to $45.9 \mu \mathrm{g} \cdot \mathrm{L}^{-1}$ in July at 
1.30 metres depth. The highest values are always found in an intermediate water layer (between $0.5-1.5$ metres depth). The largest rates of variation can be found in July with a difference of more than $40 \mu \mathrm{g} \cdot \mathrm{L}^{-1}$ of chlorophyll a along the column. However the smaller differences are found in May where the chlorophyll a values are homogeneous through the water column.

During the study period, the main phytoplankton taxa identified are Diatoms, Dinophyceae, Cryptophyceae, Prymnesiophyceae, Chlorophyceae, Prasinophyceae, colonial Cyanobacteria and picocyanobacteria although the ratio of these groups is different for each sampling campaign.

Fig. 3 shows cell densities of the different taxa through the water column for all campaigns. As it is showed Diatoms (d), Cryptophyceae (e) and Chlorophyceae (f) are found in all campaigns. However other groups like Chrysophyceae (not showed in Fig. 3) is only found in March along the whole water column and in May only in the superficial water layer. Prasinophyceae $(\mathrm{h})$ is detected in all campaigns but July, as Prymnesiophyceae (i) that is not detected in May. Finally, Dinophyceae (g) is detected through the whole column in March and May, but its presence is reduced in July and October.

Phytoplankton abundance (a) varies from $13.210^{4}$ cell. $\mathrm{L}^{-1}$ in the deepest layer of the column in July to $104.410^{6}$ cell. $\mathrm{L}^{-1}$ in October at 0.40 metres depth. The highest rates of variations in cell density are found in October where a bloom of small-centric diatoms is registered at 0.40 metres depth reaching up to $104.410^{6}$ cell.L-1 . The most abundant phytoplankton groups for all campaigns are Diatoms (d) and Cryptophyceae (e). The former is the most frequent in May and October and the second in March. However, in July the abundance of these two groups is similar throughout the water column. Chlorophyceae (f) is present in all campaigns but only 
reaches high abundance in July at surface. Other groups contribute to the total phytoplankton community in less than $10 \%$ in average.

Picophytoplankton (Fogg 1986) is represented by prokaryotic cyanobacteria (c), mainly Synechococcus (Johnson \& Sierburth 1979) which exhibit in May and July the highest densities in the middle of the water column. The highest range of variation is shown in July from $1.410^{6}$ cell.L $^{-1}(6.1$ metres $)$ to $374.610^{6}$ cell.L $^{-1}(0.9$ metres).
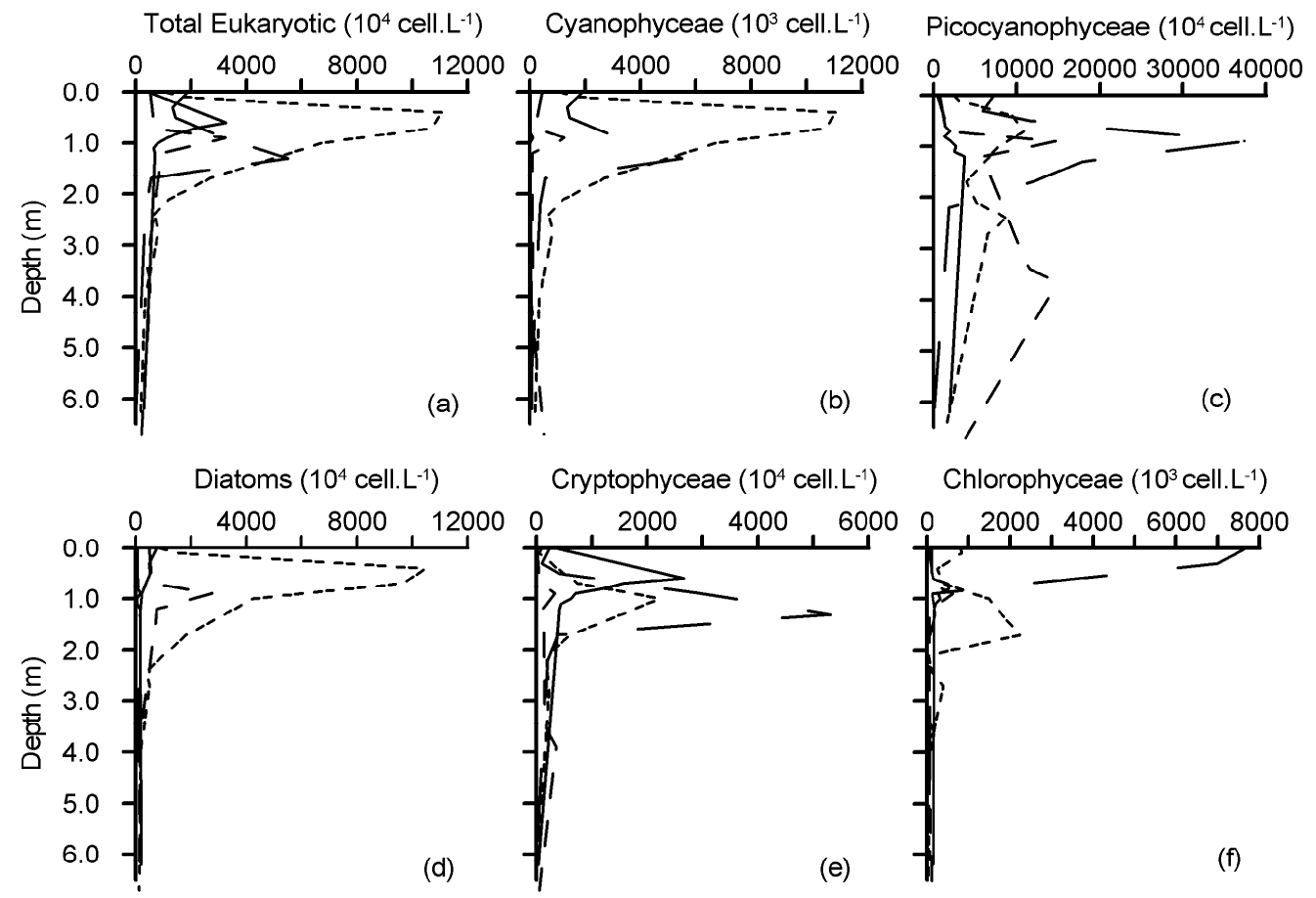

Cryptophyceae $\left(10^{4}\right.$ cell. L-1) Chlorophyceae $\left(10^{3}\right.$ cell. L-1 $)$
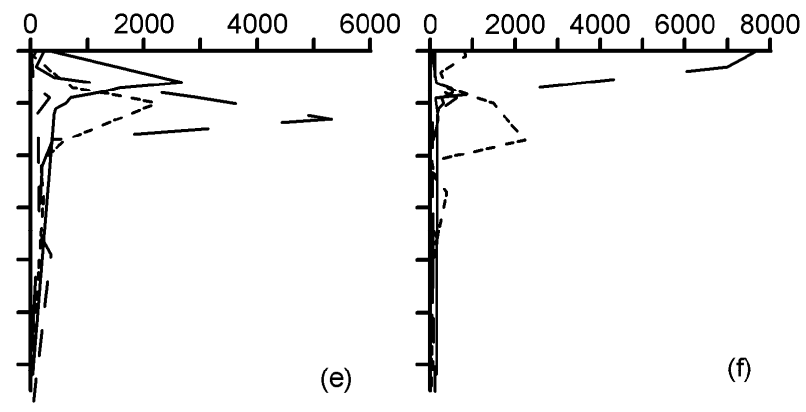

Dinophyceae $\left(10^{3}\right.$ cell. L-1)

Prasinophyceae $\left(10^{3}\right.$ cell. L-1 $)$
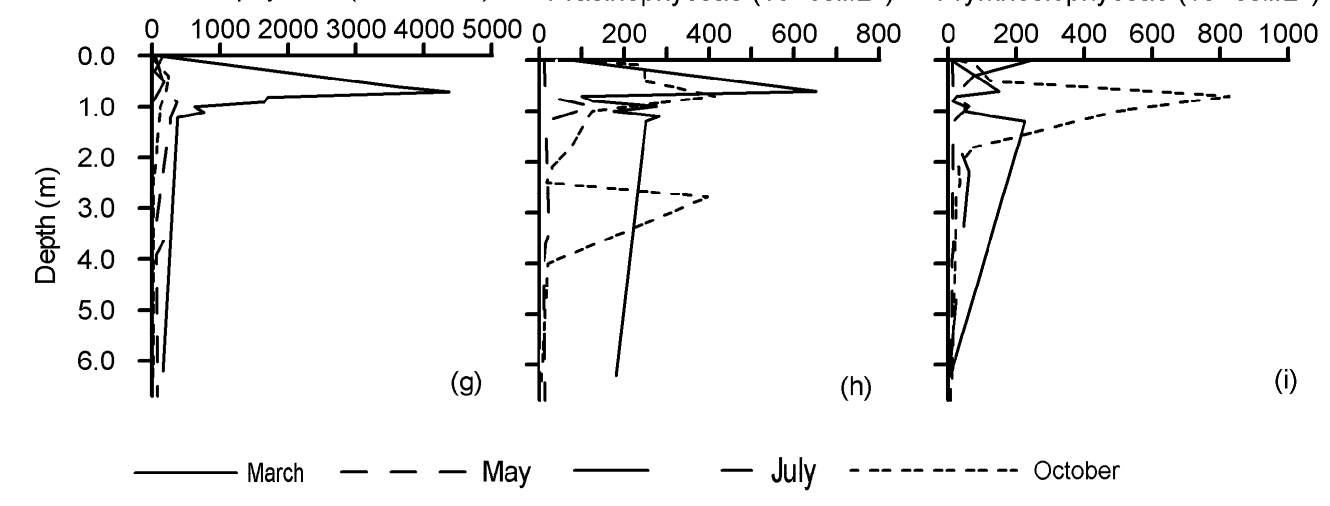

Prymnesiophyceae $\left(10^{3}\right.$ cell. L-1 $)$ 
Fig. 3: Cell densities of the main phytoplankton groups found in the Cullera Estany sampling station

\section{Relationships between phytoplankton community and environmental factors}

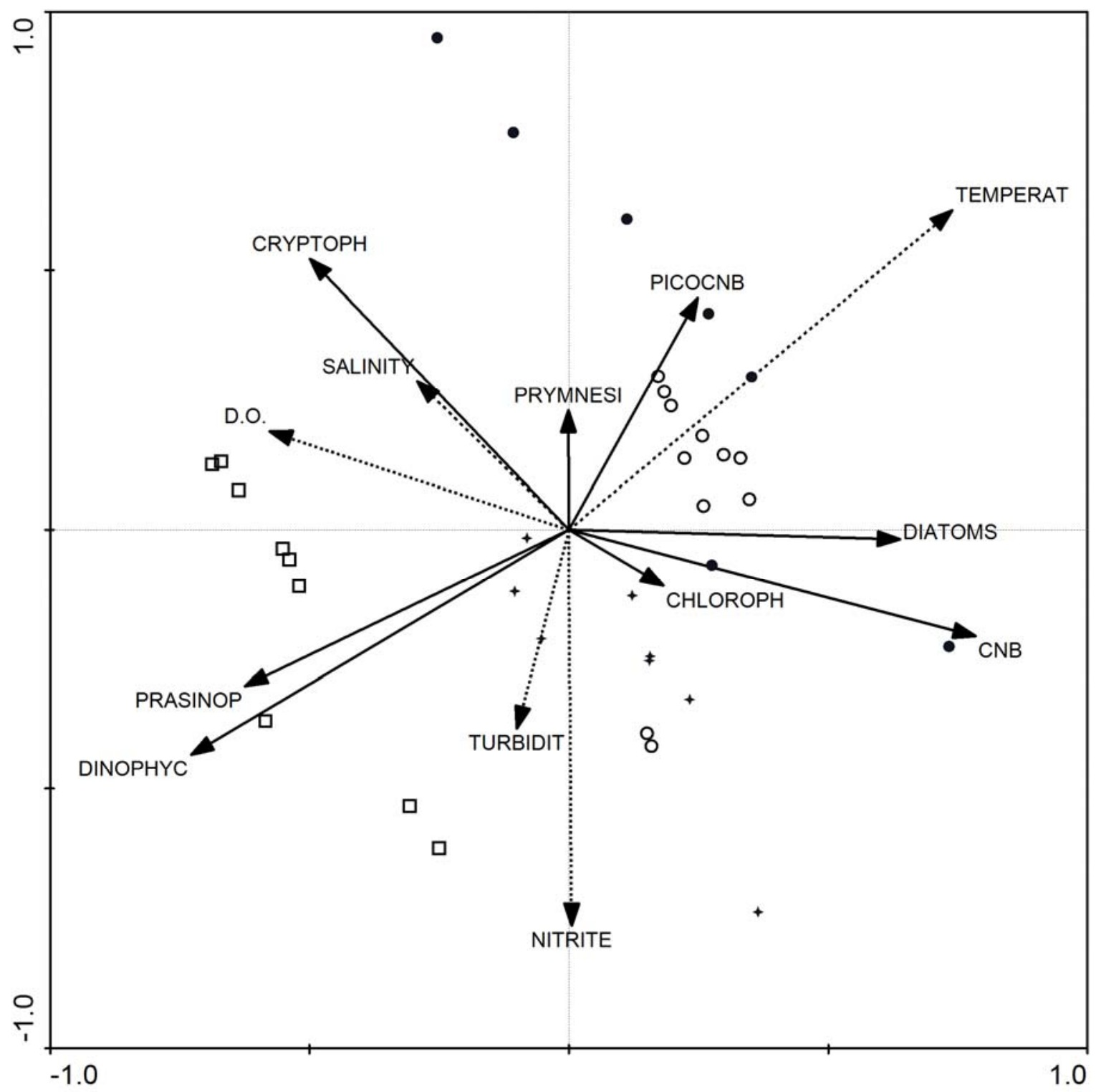

Fig. 4: Redundancy Analysis (RDA) plot showing relation phytoplankton with physico-chemical parameters. Empty square March campaign; Solid star May campaign; Solid circles July camping; Empty circles October campaign. Chloroph (Chlorophyceae); Cryptoph (Cryptophyceae); Prymnesi (Prymnesiophyceae); 
Picocnb (Picocyanophyceae); Cnb (Cyanophyceae); Prasinop (Prasinophyceae); Dinophyc (Dinophyceae)

The results of the RDA are displayed in an ordination plot for the Cullera Estany (Fig. 4). The RDA yields five environmental variables explaining the variability in the phytoplankton composition, which are Temperature $F=10.70, p=0.002$; D.O. $F=$ $5.22, p=0.004$; Nitrite $F=9.20, p=0.002$; Salinity $F=2.89, p=0.02$ and Turbidity $F=$ $2.48, p=0.042$. The relation between phytoplankton groups and environmental variables is highly significant (Monte Carlo tests: $p=0.005$ ).

In the RDA ordination the first two axes explain $48 \%$ of the total variance in the phytoplankton composition. The first axis is determined mainly by temperature, D.O. and salinity. The length of the temperature vector in the ordination plot indicates the high power of this variable to explain the positions of the biological data. This axis is significant and it describes a gradient from a relatively high temperature towards high salinity and D.O. values.

The second axis is determined by nitrite and turbidity (which limits light penetration). It is also significant and describes a gradient from relatively higher nitrite concentration and turbidity towards a cleaner and lower nutrient concentration waters.

In the ordination plot, the acute angles between two vectors indicate a high positive correlation. Thus, for the studied area Diatoms and Cyanobacteria are strongly correlated and appear on the positive side of the first axis, associated with high temperature and lower D.O. and salinity values. In addition, Prasinophyceae and Dinophyceae are powerfully correlated too. 
The Cryptophyceae vector is orthogonal to the temperature axis, implying it is unaffected by this variable. In addition, this group is strongly correlated to high salinity and D.O. concentration but also to low nitrite, indicating that this group prefers well mixed areas.

Chlorophyceae and Prymnesiophyceae show the shortest vectors placed not far from the origin of the ordination axes, meaning that these phytoplankton groups are present in all samples and not associated with one or more particular environmental variable studied.

When plotted against the environmental variables, samples of the different campaigns are distributed along the axes. In general, March samples are associated with higher salinity, D.O. and nitrite values. Prasinophyceae and Dinophyceae are the most abundant phytoplankton groups of these samples.

All May samples but one (surface sample) are located in the middle of the ordination axes. The main phytoplankton groups in this sample are Diatoms, Cyanobacteria and Chlorophyceae.

In July campaign samples are distributed in the positive side of the two axes where higher temperatures and lower nutrient content and salinity prevail. Furthermore, samples from this campaign are wide open distributed along the diagram indicating that environmental conditions are different along the water column due to the presence of a sharper halocline. The phytoplankton composition of the surface is mainly compound of Diatoms, Chlorophyceae and filamentous Cyanobacteria. However in the deepest layers of the water column, phytoplankton composition changes completely as Cryptophyceae and Prymnesiophyceae dominate the community. 
Finally, the October campaign that also has temperature stratification, shows all samples but two, distributed closely and on the positive side of the two axes. The main phytoplankton groups related to October samples are Diatoms and Prymnesiophyceae. Those samples located away correspond to the superficial water, indicating that environmental conditions in this layer are different.

\section{Discussion}

\section{Environmental factors}

In this ecosystem, the change of physical, chemical and biological parameters is mainly related to inland-sea water interaction which depends mainly on natural factors and on the anthropogenic regulation of water fluxes in the channels. From the analysis of each sampling campaign four different scenarios are found in Cullera Estany. In March there is no great temperature, or TP variation through the water column. However nitrate values suffer great variations since concentration in surface is the highest in all campaigns. This may be because is the fertilization period for rice crops around, which are based on nitrogen, and to the rains that occurred in the first days of March (AEMET 2011). Moreover there is an increase in phytoplankton biomass that generates larger D.O. concentrations. On the contrary, in the deepest layer of the water column, phytoplankton cells may die, reduce D.O. values and increase nitrite values at the bottom of the column (Falco 2003). In May campaign there is no great temperature, salinity or chlorophyll a value variation either. However, although there is no stratification in the water column anoxia/hypoxia conditions are reached at the bottom. This is due to the fact that mineralization of this biomass at the bottom is oxygen-consuming leading to a decrease in D. O. concentration. Beside this, a strong redox potential gradient is also developed in this campaign with values ranging from $50 \mathrm{mV}$ to $-200 \mathrm{mV}$ (values 
obtained from the multiparametric probe YSI but not showed). At 6 metres depth redox potential turns into negative values affecting to nutrient concentrations since ammonium, TP, orthosilicic acid and SRP increase due to remineralization within the sediments.

From late spring the freshwater flow dominates, establishing in July a marked stratification of fresh and salt water. The origin of this freshwater is due to irrigation water returns from the crop near the lagoon since in summer period irrigation and fertilization are intensified (Lidón et al. 1999). Thus, the highest salinity values are always in the deepest part of the lagoon and may come from the sea.

In addition, there is a biomass peak at 1.30 metres probably due to the saline shock that produce senescence and subsequent sedimentation in the halocline. During this sedimentation process, the cells of affected organisms are hold in the halocline (which is a calm zone), where they are accumulated producing vertical distribution peaks (Falco et al. 2006). This biomass decomposes at the bottom of the column leading to anoxia conditions. The mineralization process leads to the highest ammonium, TP, SRP and orthosilicic acid values for all the campaigns. Furthermore, the redox potential gradient through the column varies from $0 \mathrm{mV}$ to $-250 \mathrm{mV}$, and it turns into negative values at 4 metres depth.

Finally, October campaign also has a saline stratification and a sharp variation in temperature, registering the superficial water layer colder and fresher than the bottom. The high nitrate and orthosilicic acid content that show this superficial layer suggest its continental origin (Falco et al. 2006). The large rate of nitrate variations in October (rainfall season) is due to the surplus of water leached which elevates the amount of nitrogen. 
Although there are few published studies related to the physical and chemical characterization of the Cullera Estany, the results obtained are in concordance with those achieved by Marti (2007) unpublished data, and Falco et al. 2006 (oral communication) where a high salinity stratification in the water column was found mainly produced by freshwater inputs. It was also found that in the freshwater layer, O.D., nitrite, nitrate and chlorophyll a values were always higher. However SRP, TP, and orthosilic acid concentrations vary greatly. Organic matter mineralization caused anoxia phenomenon from 3 metres deep on, mainly in the middle of the coastal lagoon and during spring and summer. Finally, it was also found a chlorophyll a peak in the halocline and chemocline.

\section{Biological data}

The Estany phytoplankton composition varies widely in time due to the significant fluctuations in environmental parameters. According to RDA analysis results, temperature and nitrite are the most important environmental factors modifying the phytoplankton composition. The rather low percentage of variance in the phytoplankton data explained by the environmental variables in the RDA is quite common in complex ecological monitoring data (ter Braak \& Smilauer 1998), and it is partly due to other factors, not considered in this study, influencing the phytoplankton population (e.g. grazing, sedimentation, micronutrients). In March campaign, Prasinophyceae (pico and nano cell-size) and Dinophyceae are the most correlated taxa. This may be due to the fact that Dinophyceae are considered to be favoured when small-celled species exist since many of them are mixo or heterotrophs (Suikkanen et al. 2007). In addition, these groups are abundant in winter and in muddy but well oxygenated zones. 
However, the phytoplankton composition shifts towards Diatoms and Cryptophyceae dominance in May campaign. In freshwater environments some Cryptophyceae taxa are often present in constant but relatively low numbers throughout the year, although sudden population increases are also common (Novarino 2003). This seems to happen in this campaign where in the middle water column Cryptophyceae reaches a $96 \%$ abundance percentage.

In July the high water stratification conditions may induce shifts in phytoplankton composition. In the superficial layer Diatoms and Chlorophyceae are abundant. The increase in Chlorophyceae may be associated with the decrease in salinity, as many of the common Chlorophytes are of freshwater origin. However Cryptophyceae increases its proportion in the middle depth of the column as this group generally appears during the stratification period in the Cullera Estany due to the greater motility characteristics and size of these organisms (Rojo et al. 1986). Mediterranean climate is characterized by a strong seasonality in rainfall period (Ramos 2001). During this year, the highest rainfalls occurred in October before the sampling date (AEMET 2011). This fact generates another change in the phytoplankton composition since fast-growing small-celled centric Diatoms reach the highest density in this campaign during the entire water column. This may be due to the fact that silicate inputs are mainly fluvial and therefore this silica-dependent group is favoured to growth. This relationship would explain the relative decrease in the abundance of Dinophyceae and other non-siliceous species.

The results obtained in this study are in concordance with those achieved by Rojo and Miracle (1984) and Rojo et al. (1986) in the Cullera Estany. In these studies water samples were taken at different depths during an annual cycle. The same phytoplankton groups were identified and different groups of association of 
phytoplankton were characterized. Some of the best defined phytoplankton associations were first, a group composed mainly by small centric diatoms, which can be considered as one of the first succesional stages in spring time. Another group detected was made up by Cryptophyceae and several Chlorophyceae founded in the upper part of the water column, which succeeds in early summer. And, finally, a group composed mainly by fast-growth of small centric diatoms characteristic of fluctuating conditions. In addition, Chrysophyceae and Euglenophyceae were detected in a short period of time as it happens in our study. Available data from picophytoplankton in the Cullera Estany are scarce since most of the published data are based on inverted microscopy and this technique neglect picophytoplankton and many nano-sized organisms (Domingues et al. 2008). However, studies of picophytoplankton seasonal variations performed in temperate areas found highest picoplankton abundance in summer when water temperature reaches its maximum (Caroppo 2000) as it happens in the Cullera Estany. Regarding the WFD phytoplankton is the only planktonic element to be considered for this water body (Annex V). Thus, several phytoplankton-related variables (composition, abundance and biomass), are required to be evaluated by member states. Furthermore another physico-chemical parameters need to be studied (salinity and thermal, nutrient and oxygenation conditions). Results obtained in this research related to phytoplankton, nutrients and salinity may be considered as a starting point for future WFD implementation activities.

\section{Conclusions}

1) May and July campaigns exhibit anoxic/hypoxic conditions and similar nutrient patterns different from those obtained in March and October. 
2) Although there is a seasonal pattern linked to freshwater and marine inputs, the main environmental factor affecting nutrient distribution along the water column is the presence of anoxic/hypoxic conditions.

3) Diatoms, Chlorophyceae and Cryptophyceae are the most abundant groups in the Cullera Estany, although Dinophyceae and Prasinophyceae are also present in some campaigns.

4) Changes in phytoplankton community composition have been detected among the sampling campaigns. Diatoms and Cryptohyceae are the most abundant groups although their composition shifts both in surface and in the middle depth layer during the study period linked to environmental factors such temperature, salinity, D.O. and nitrite.

5) Composition, abundance and biomass data on the phytoplankton community in Cullera Estany are provided which will be helpful in future WFD implementation works by the regional government.

\section{Acknowledgements}

This research work has been supported by the Generalitat Valenciana.

\section{References}

Agencia Estatal de Meteorologia. AEMET. (2011)

ftp://ftpdatos.aemet.es/series climatologicas/valores diarios/estacion/. December. APHA. (1998) Standard methods for the examination of water and wastewater, 20th edition. Washington, DC: American Public Health Association, American Water Works Association, Water Environment Federation. 
Brogueira, M.J., Oliveira, M.R. and Cabeçadas, G. (2007) Phytoplankton community structure defined by key environmental variables in Tagus estuary, Portugal. Mar Environ Res 64, 616-628.

Caljon, A. (1983) Brackish-water phytoplankton of the Flemish Lowland (developments in hydrobiology; 18) Dr W. Junk Publishers, The Hague. ISBN 906193-769-8

Caroppo, C. (2000) The contribution of picophytoplankton to community structure in a Mediterranean brackish environment. J Plankton Res 22, 381-397.

Cloern, J.E. (2001) Our evolving conceptual model of the coastal eutrophication problem. Mar Ecol Progr Ser 210, 223-53.

Council of European Communities. (2000) Directive 2000/60/EC of the European Parliament and of the Council establishing a framework for the Community action in the field of water policy (2000/60/EEC) Official Journal (OJ L 327)

Domingues, R., Barbosa, A. and Galvao, H. (2008) Constraints on the use of phytoplankton as a biological quality element within the Water Frame Directive in Portuguese waters. Mar Pollut Bull 56, 1389-1395.

Ettl, H. (1983) Süßwasserflora von Mitteleuropa. Chlorophyta I Phytomonadina. Gustav Fisher Verlag. Stuttgart New York.

Falco, S. (2003). Comportamiento de los nutrientes en un estuario estratificado: Caso del Delta del Ebro. Valencia, Spain: Universidad Politécnica de Valencia, Ph.D. thesis, $481 p$.

Falcó, S., Romero, I., Rodilla, M., Sierra, J.P., del Río, J.P., Mosso, C. and Perez, M.C. (2006) Chlorophyll a and phytoplankton maximum at the halocline of Ebro River Estuary. J Coastal Res SI 39, 526-530.

Fogg, G.E. (1986) Picoplankton. Proc R Soc Lond 228,1-30. 
Havskum, H., Schlüter, L., Scharek, R., Berdalet, E. and Jacquet, S (2004) Routine quantification of phytoplankton groups - microscopy or pigment analyses? Mar ecolprog ser 273, 31-42

Johnson, P.W. and Sieburth, J,M. (1979) Chroococcoid cyanobacteria in the sea: A ubiquitous and diverse phototrophic biomass. Limnol Oceanogr 24, 928-935.

Kirkwood, D., Aminot, A. and Pertilla, M. (1991) Report on the results of the fourth intercomparison exercise for nutrients in sea water. ICES Cooperative Research Report 174.

Lidón, A., Ramos, C. and Rodrigo, A. (1999) Comparison of drainage estimation methods in irrigated citrus orchards. Irrig Sci 19, 25-36.

Mösso, C., Sierra, J.P., Rodilla, M. and Romero, I. (2008) High vertical resolution sampling in density interfaces of estuaries and river plumes. Estuar Coast 31, 258268.

Novarino, G. A. (2003) A companion to the identification of cryptomonad flagellates (Cryptophyceae $=$ Cryptomonadea). Hydrobiologia 502, 225-270.

Paches, M., Romero, I., Hermosilla, Z. and Martínez-Guijarro, R. (2012) PHYMED: An ecological classification system for the Water Framework Directive based on phytoplankton community composition. Ecol Indic. 19, 15-23.

Parsons, Tr., Maita, Y. and Lalli, C.M. (1984) A manual of chemical and biological methods for seawater analysis. Pergamon Press. New York.

Perez-Ruzafa, A., Gilabert, J., Gutiérrez, J.M., Fernández, A.I., Marcos, C. and Sabah, S. (2002) Evidence of a planktonic food web response to changes in nutrient input dynamics in the Mar Menor coastal laggon, Spain. Hydrobiologia 475, 359-369. 
Puigserver, M., Ramon, G., Moyà, G. and Martinez-Taberner, A. (2002) Planktonic chlorophyll a and eutrophication in two Mediterranean littoral systems (Mallorca Island, Spain). Hydrobiologia 475, 493-504.

Ramos, C., Agut, A. and Lidón, A. (2002) Nitrate leaching in important crops of the Valencian Community region (Spain). Environ Pollut 118, 215-223.

Ramos, M.C. (2001) Rainfall distribution patterns and their change over time in a Mediterranean area. Theor appl climatol 69, 163-170.

Rojo, C. and Miracle, R. (1984) Fluctuación estacional de las poblaciones fitoplanctónicas del Estany de Cullera (Valencia). Anales de biología, 2 (Sección especial, 2) Universidad de Murcia (Spain) 161-168.

Rojo, C., Miracle, M.R. and Serra, M. (1986) Interrelación entre las especies de microalgas halladas en el Estany de Cullera (Valencia) Limnetica 2, 3540. Round, F.E., Crawford, D. and Mann, G. (1990) The Diatoms. Biology and morphology of the genera. Cambridge University Press Sournia, A. (1978) Phytoplankton Manual. Monographs on oceanographic methodology UNESCO. Paris.

Suikkanen, S., Laamanen, M. and Huttunen, M. (2007) Long-term changes in summer phytoplankton communitites of the open Northern Baltic Sea. Estuar Coast Shelf S 71, 580-592.

ter Braak, C.J.F. (1986) Canonical correspondence analysis: a new eigenvector technique for multivariate direct gradient analysis. Ecology 67, 1167-1179.

ter Braak, C.J.F. and Šmilauer, P. (1998) CANOCO Reference Manual and User's Guide to CANOCO for Windows: Software for Canonical Community Ordination (version 4). Microcomputer Power Ithaca New York.

Tomas, C. (1997) Identifying marine phytoplankton. Academic Press. 
Treguer, P. and Le Corre, P. (1975) Manuel d'analyse des sels nutritifs dans l'eau de mer. Université de Bretagne Occidentale, Brest.

Vargo, G.A. (1978) Using a fluorescence microscope. Phytoplankton manual. Monographs on Oceanography Metodology UNESCO, 108-112.

Vicente, E. and Miracle, M.R. (1988) Estructura y función de los procariotas en dos ecosistemas lagunares costeros: L'albufera de Valencia y l'Estany de Cullera. Actas del Congreso de Biologia Ambiental. Il Congreso Mundial Vasco pp. 79-108. ISBN84-7585-146-0.

Reynolds, C. (2006) Ecology of phytoplankton. Cambridge University Press

\section{Word count}

5029

\section{Figure legends}

Fig. 1: Cullera Estany on the north-western Mediterranean coast. Location of sampling station. A-G irrigation channels

Fig. 2: Vertical profiles of physical and chemical parameters for the sampling station Fig. 3: Cell densities of the main phytoplankton groups found in the Cullera Estany sampling station

Fig. 4: Redundancy Analysis (RDA) plot showing relation phytoplankton with physico-chemical parameters. Empty square March campaign; Solid star May campaign; Solid circles July camping; Empty circles October campaign

\section{Table}

Table 1. Dates and depth profiles for the sampling station 


\begin{tabular}{|c|c|}
\hline Date & Depths (metres) \\
\hline the $2^{\text {nd }}$ of March & $0.0,0.6,0.7,0.8,0.9,1.0,1.1,1.2,6.2$ \\
\hline the $4^{\text {th }}$ of May & $0.0,0.7,0.9,1.2,3.4,3.6,3.9,6.7$ \\
\hline the $13^{\text {th }}$ of July & $0.0,0.3,0.5,0.9,1.3,1.7,2.2,6.1$ \\
\hline the $20^{\text {th }}$ of October & $0.0,0.1,0.4,0.7,1.0,1.7,2.1,2.4,2.7,4.0,6.4$ \\
\hline
\end{tabular}

